\title{
OPEN INNOVATION: AN ASSESSMENT OF CRITICAL SUCCESS FACTORS USING ANALYTIC HIERARCHY PROCESS
}

\section{Christian Tabi Amponsah, PhD., Yorkville University \\ ABSTRACT}

This paper explores the critical success factors for open innovation in systematization of knowledge exploration, and exploitation to expedite internal innovation and extricate the market for commercialization of business activities. Drawing on extant literature on open innovation and expert opinion from leading innovation firms listed in the Thomas Reuters Derwent World Patents Index covering North America, Europe, Asia, Sub-Saharan Africa, the Middle East and North African, a plethora of factors were developed and finalized as success factors for open innovations. The Analytic Hierarchy Process, noted for its flexibility, systematic, robustness, and repeatable evaluation, was used to prioritize the factors and finally ranked in critical order. The findings suggest areas that organizations need to pay attention to for potential success of their innovation programs. The study concludes among others that, the accumulation of external knowledge and its dissimilation positively impacts the systematizing of innovativeness in organizations.

Keywords: Critical success factors, knowledge exploitation, knowledge exploration, open innovation

\section{Introduction}

In the past, organizations relied on their internal knowledge (closed innovation) to develop and nurture ideas within until they are launched as new product or business. This was viewed as a strategic asset, and in some cases even as a market entry barrier (Chesbrough, 2003). As a result of changes in the economic market place, increased complexities of product development, technological changes, the rising cost of innovation as well as short product development lead times, many organizations are now compelled to open up their innovative activities and to enter not only into different forms of partnerships but also new forms (Feller, Finngan, Hayes and O’Reilly, 2009).

Open innovation allows ideas to flow in and out of an organization through what can be described as porous boundaries (Vanhaverbeke, 2005; Chesbrough, 2003). Used first by Chesbrough (2003), the term open innovation suggests that "firms can and should use external as well as internal ideas and paths to market as they look to advance their technology" (p. 24). The concept is used to describe innovation processes in which firms 
Open Innovation: An Assessment of Critical Success Factors Using Analytic Hierarchy Process. A paper submitted to the International Symposium of the Analytic Hierarchy Process 2018, Hong Kong, HK.

interact extensively with their environment, leading to a significant amount of external knowledge exploration and exploitation.

Extensive literature has shown that both exploratory and exploitative innovation contribute to firm performance (e.g., Hortinha, Lages, \& Lages, 2011; Lisboa, Skarmeas, $\&$ Lages, 2011), yet they differ greatly in many respects, for example, in their antecedents and the conditions needed for their success. As such, a great deal of research has been conducted to shed light on the concept of open innovation and factors that contribute to the success or otherwise in organizational performance. This study sets to explore how knowledge flow between the organization and its external environment happens, how organizations change from a closed innovation system to an open one, and when and why do they change. Additionally, the study examines the implications that open innovation success factors have on organizations and addresses critical aspects of which we need a better understanding. The study therefore seeks to answer: what are the critical success factors of the open innovation process as derived from the empirical research literature using analytic hierarchy process? There has been a growing request for determination of critical success factors for systematization and areas that organizations need to pay attention to the most in open innovation (Amponsah \& Adams, 2017). This paper sets to examine empirical research on open innovation processes and identify factors that support successful implementation of the process, which is an area of growing interest to academics and practitioners using the analytic hierarchy process.

\section{Literature Review}

The study draws on extant literature on knowledge exploitation and exploration of the open innovation paradigm. In addition, expert opinion from leading innovation firms listed in the Thomas Reuters Derwent World Patents Index covering North America, Europe, Asia, Sub-Saharan Africa, the Middle East and North African was sort. These systematic processes yielded a plethora of success factors which were finalized as success factors for open innovations.

According to Chesbrough (2004), the open innovation paradigm assumes that "organizations can and should use external as well as internal ideas, and internal and external paths to market, as they look to advance their technology" p. 23. Accordingly, the concept has been used to describe innovation processes in which firms interact extensively with their environment, leading to a significant amount of External Knowledge (EK), Knowledge Exploration (KET), and Knowledge Exploitation (KEL). To link open innovation framework to related literature, Lichtenthaler (2011, p. 77) proposes an expanded definition of open innovation as "systematically performing KET, retention and exploitation inside and outside an organization's boundaries throughout the innovation process".

Despite its growing importance, many firms experience severe challenges in actively managing the processes of open innovation (van de Vrande et al., 2009), 
Open Innovation: An Assessment of Critical Success Factors Using Analytic Hierarchy Process. A paper submitted to the International Symposium of the Analytic Hierarchy Process 2018, Hong Kong, HK.

although there is evidence to show that some companies, such as Procter \& Gamble, Apple and Samsung, have afforded great benefits from the open innovation construct (Schwartz \& Huff, 2010). Though there has been some work in the area to systematize the open innovation process across organizations by adding value to the existing work of exploring knowledge for organizational development, such activities categorize the factors for open innovation and therefore leave the implementation aspect to the whims and caprices of potential users. Thus, practitioners and academics alike need a better understanding of open innovation processes in order to grasp the benefits while avoiding potential pitfalls rather than a trial and error approach (Gassmann \& Enkel, 2004). Gassmann \& Enkel. (2004), for example, have suggested the need for researchers to develop a multilevel conceptual framework for organizing open innovation in firms. Similarly, many of the studies on open innovation provide general prescriptions and do not take into consideration many contexts and contingencies that influence the innovation process (Tidd, 2014). This has necessitated the search for critical success factor (CSF) for the open innovation process.

By definition, critical success factors are "those few key areas of activity in which favorable results are absolutely necessary for a particular manager to reach his or her own goals...those limited number of areas where "things must go right"" (Rockart, 1982, p.2). Critical success factors measure end results, as such authors such as Ghosh, Liang, Meng \& Chan (2001) see CSF as key success factors as critical for excellent performance of the company, rather than just survival. Therefore, assessing the critical success factors facilitating open innovation process will increase the prospects of success.

\section{Objectives}

The objective of this study is to examine the critical success factors for systematization of a firm's external knowledge exploitation and knowledge exploration processes that influence the firm's commercialization activities and overall performance. Although exploration and exploitation may compete for resources and that there are trade-offs between the two (Lavie et al., 2010), we follow prior research and argue that exploratory and exploitative innovation can be pursued simultaneously at the organizational level (Bierly \& Daly, 2007).

\section{Research Design/Methodology}

The study uses systematic review of literature with the aim of determining current status of research on open innovation in order to identify success factor. Based on Thomas

Reuters Derwent World Patents Index, seven industrial categories, that is, aerospace and defense, ITC, automotive, home appliances, medical devices pharmaceutical/ biochemistry and semi-conductors were sourced and used for the study. In the process, 30 factors were identified and categorized for the study. The Analytic Hierarchy Process (AHP) a decision-aiding method developed by Saaty (1980, 1985 \&1990) was deployed 
Open Innovation: An Assessment of Critical Success Factors Using Analytic Hierarchy Process. A paper submitted to the International Symposium of the Analytic Hierarchy Process 2018, Hong Kong, HK.

in the study. It aims at quantifying relative priorities for a given set of alternatives on a ratio scale, based on the judgment of the decision-maker, and stresses the importance of the intuitive judgments of a decisionmaker as well as the consistency of the comparison of alternatives in the decision-making process (Saaty, 1980). Since a decision-maker bases judgment on knowledge and experience then makes decisions accordingly, the AHP approach agrees well with the behavior of a decision-maker. The strength of this approach is that it organizes tangible and intangible factors in a systematic way, and provides a structured yet relatively simple solution to the decision-making problems (Skibniewski \& Chao 1992). In addition, by breaking a problem down in a logical fashion from the large, descending in gradual steps to the smaller and smaller, one is able to connect, through simple paired comparison judgments, the small to the large.

\section{Data/Model Analysis}

By following the AHP outline indicated above, the hierarchy of the problem can be developed for the open innovation factors as shown in Figure 1. The following can be done manually or automatically by using the Expert Choice software.

1. Synthesizing the pair-wise comparison matrix

2. Calculating the priority vector for a criterion such as technology

3. Calculating the consistency ratio

4. Calculating $\lambda \max$

5. Selecting appropriate values of the random consistency ratio from a table, and

6. Checking the consistency of the pair-wise comparison matrix to assess whether the decisionmakers' comparison was consistent or not. 
Open Innovation: An Assessment of Critical Success Factors Using Analytic Hierarchy

Process. A paper submitted to the International Symposium of the Analytic Hierarchy Process 2018, Hong Kong, HK.

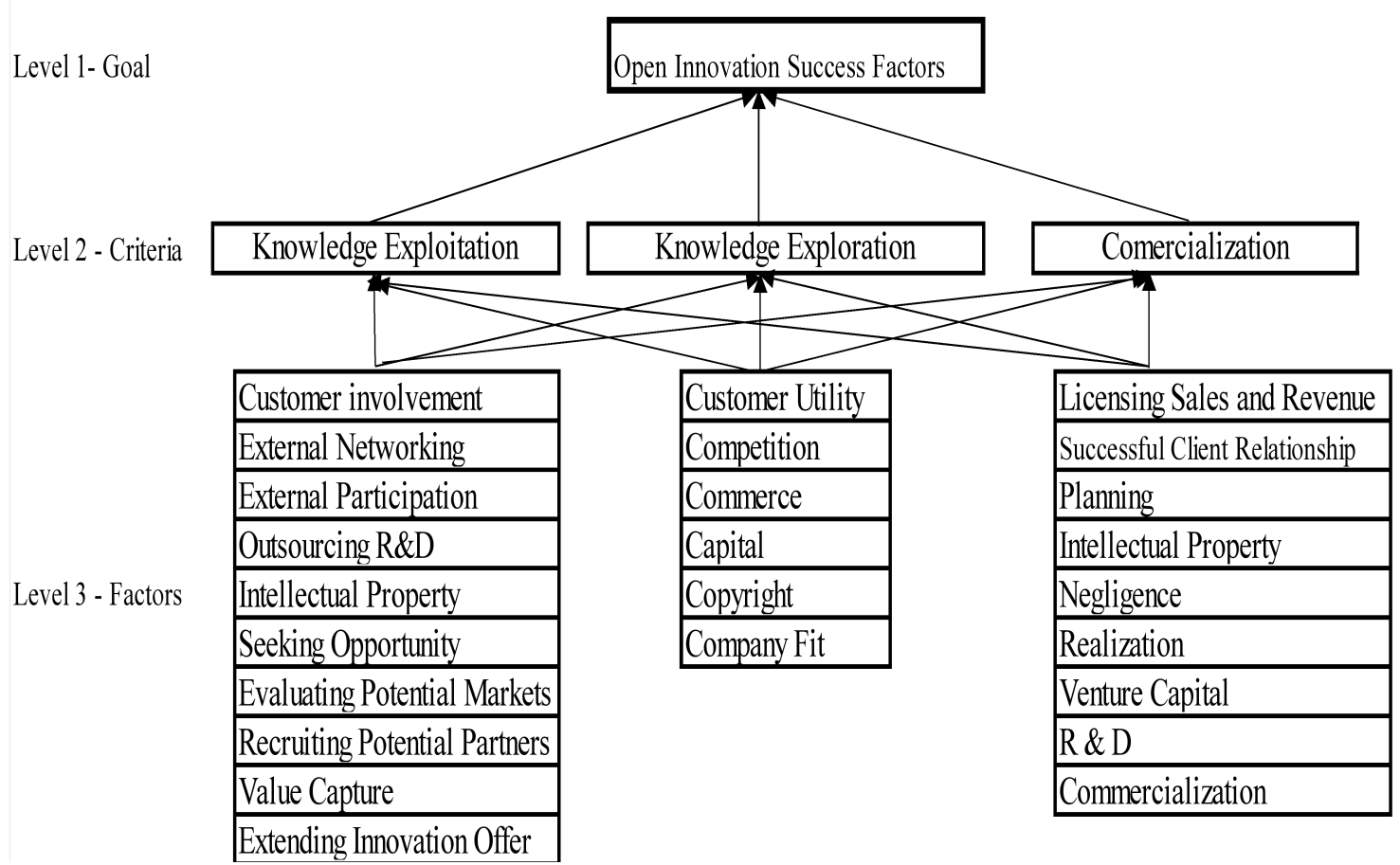

Figure 1: Hierarchy of Open Innovation Success Factors

\section{Limitations}

The present study is not without its limitations. The choice of search procedure meant total coverage of all the relevant empirical search on the open innovation process was not achieved. Papers may therefore have been included that did in fact address the open innovation process, but because of conceptual ambiguity were not included. Yet, if the era of open innovation really has started, then this procedure is certainly well justified. Finally, this paper proposes some research directions that are not exhaustive but rather represent the initial stages of a new line of inquiry. Further research can also be carried out with a larger sample across more organizations from different industries and regions in order to obtain more validated information that can be analyzed to draw conclusions on the various aspects and determinants of the open innovation process.

\section{Conclusions}

By crafting a model that systematizes KET and KEL in open innovation, this paper

adds to the understanding of the role of open innovation, process, systematization, content and context, as well as the research and development side of open innovation. The study has numerous contributions to make to open innovation discourse. Firstly, we extend discussions on open innovation and argue that systematization of 
Open Innovation: An Assessment of Critical Success Factors Using Analytic Hierarchy Process. A paper submitted to the International Symposium of the Analytic Hierarchy Process 2018, Hong Kong, HK.

open innovation requires the balancing act of KET ambidexterity and exploitation for commercialization of the firm, and that there is a mediated relationship between these variables. Secondly, by identifying the gap which mitigates the knowledge transfer through an organized medium in commercializing new ideas and technology thereby integrating the exploration and exploitation process, we provide a new threshold of insight that will help organizations widen the horizons of their technological arena. Thirdly, the outcome of this study provides an understanding of the need for a business model which further streamlines the acceptance and institutionalizing of the open innovation process in organizations, regardless of the size of the organization.

\section{References}

Amponsah, C.T., \& Adams S. (2017). open innovation: systematisation of knowledge exploration and exploitation for commercialisation. International Journal of Innovation Management 21, (3) 1750027-1-26. DOI: 10.1142/S136391961750027X

Bierly, P.E., \& Daly, P.S. (2007). Alternative knowledge strategies, competitive environment, and organizational performance in small manufacturing firms, Entrepreneurship Theory and Practice, 31(4), 493-516.

Chesbrough, H.W. (2004). Managing Open Innovation. Research Technology Management, 47 (1) pp. 23-26.

Chesbrough, H.W. (2003). The era of open innovation, Sloan Management Review, 44(3),35-41.

Feller, J., Finnegan, P. Hayes, J., \& O’Reilly, O. (2009). Institutionalizing information asymmetry: governance structures for open innovation. Information Technology \& People, vol. 22, no. 4, pp. 297-316, 2009.

Gassmann, O and E Enkel (2004). Towards a theory of open innovation: Three core process archetypes, Proc. R\&D Management Conf., pp. 1-18. July 6-9Lisbon, Portugal

Ghosh, B. C., Liang, T. W., Meng, T. T., \& Chan, B. (2001). The key success factors, distinction capabilities and strategic thrusts of top SMEs in Singapore. Journal of Business Research, 51, 209-221.

Hortinha, P., Lages, C., \& Lages, L. (2011). The trade-off between customer and technology orientations: Impact on innovation capabilities and export performance. Journal of International Marketing, 19 (3), 36-58.

Lavie, D., Stettner, U., \& Tushman, M. L. (2010). Exploration and exploitation within And across organizations. The Academy of Management Annals, 4(1): 109-155.

Lichtenthaler, U. (2011). Open innovation: Past research, current debates, and futuredirections. Academy of Management Perspectives, 25(1), 75-93. doi: 10.5465/AMP.2011.59198451.

Lisboa. A., Skarmeas, D., \& Lages, C. (2011). Innovative capabilities: Their drivers and effects on current and future performance, J Bus Res doi: 10.1016/j.jbusres.2011.06.015

van de Vrande, de Jong, J. J., \& Vanhaverbeke, W. (2009). Open Innovation in SMEs: 
Open Innovation: An Assessment of Critical Success Factors Using Analytic Hierarchy Process. A paper submitted to the International Symposium of the Analytic Hierarchy Process 2018, Hong Kong, HK.

Trends, motives and management challenges. International Small Business Journal, DOI: $10.1177 / 0266242612472214$.

Rockart, J.F. (1982). The changing role of the information system executive: a critical success factor perspective. Sloan Management Review 24 (1), 2-13

Saaty, T.L. (1990). How to make a decision: the analytic hierarchy process. European Journal of Operational Research, North-Holland pg.48:9.

Saaty, T.L. (1985). Decision making for leaders. Belmont, California: Life Time Leaning Publications.

Saaty, T.L. (1980). The analytic hierarchy process. New York: McGraw- Hill,

Schwartz, K and B Huff (2010). The story of Eli Lilly's open innovation journey: How One company developed a mature model. PDMA Visions, pp. 19-22.

Skibniewski, M.J. and Chao, L. (1992) Evaluation of Advanced Construction Technology with AHP Method. Journal of Construction Engineering and Management, ASCE, 118, 577-593. http://dx.doi.org/10.1061/(ASCE)07339364(1992)118:3(577)

Tidd, J. (2014). Open Innovation Research, Management and Practice. Series on Technology Management, Vol. 23. London: Imperial College Press. ISBN 9781783262809.

Vanhaverbeke, W (2006). The inter-organizational context of open innovation. In Open Innovation: Researching a New Paradigm, W.H. Vanhaverbeke and J West (Eds.), pp. 205-219. Oxford: Oxford University Press. 